\title{
Laparoscopic or Minimally Invasive Surgery in the Treatment of Cervical Cancer
} \author{
Álvarez Castro ${ }^{5}$, Olga Vanessa Manrique Arismendy ${ }^{6}$ \\ ${ }^{1}$ General Medical of the San Martín University Foundation \\ ${ }^{2}$ General Medical University of Rosario \\ 3Intern Medical at the University of Sinú \\ ${ }^{4}$ General Medical Cooperativa University of Colombia \\ ${ }^{5}$ General Medical University of Sinú, Montería, Colombia \\ ${ }^{6}$ Medical Student Pedagogical and Technological University of Colombia
}

Vanessa Carrillo Redondo ${ }^{1 *}$, Mariana Borras Osorio ${ }^{2}$, Jairo Jesús Martínez Romero ${ }^{3}$, Angie Katerine Rodríguez Paredes ${ }^{4}$, Yamith de Jesús

*Corresponding Author: Vanessa Carrillo Redondo, General Medical of the San Martín University Foundation, Colombia.

Received date: August 13, 2021; Acc epted date: September 26, 2021; published date: October 30, 2021

Citation: Vanessa C. Redondo., Mariana B. Osorio., Martínez Romero JJ, Rodríguez Paredes AK, Álvarez Castro YDJ. et all (2021) Laparoscopic or Minimally Invasive Surgery in the Treatment of Cervical Cancer. J.Women Health Care and Issues, 4(8); DOI:10.31579/2642-9756/084

Copyright: (C) 2021 Vanessa Carrillo Redondo, This is an open access article distributed under the Creative Commons Attribution License, which permits unrestricted use, distribution, and reproduction in any medium, provided the original work is properly cited.

\begin{abstract}
:
Cervical cancer is the most common cause of death in female patients over 45 years of age. Surgical treatment (laparoscopic total hysterectomy and radical hysterectomy plus laparoscopic pelvic lymphadenectomy) is the most curative therapeutic resource in the initial stages (Ia1, Ia2 and Ib1). The treatment adopted in the development of this pathology is fundamental as the technique used to determine the prognosis of cervical cancer and obtain information on lymphatic involvement. Imaging techniques have advanced in recent years, but the only reliable way to detect lymph node involvement is the pathological study of the extracted pieces. The goal of laparoscopic staging is to assess bladder, bowel, and lymph node involvement and intra-abdominal disease. Laparoscopic pelvic and lumboaortic lymphadenectomy is effective in staging and treating gynecologic cancers. Laparoscopic lumboaortic lymphadenectomy has few complications, rescues an acceptable number of lymph nodes, and requires a shorter hospital stay. In addition, it identifies cervical cancers that require extended-field radiation therapy.
\end{abstract}

Key words: lymphadenectomy; laparoscopic-vaginal; cervical cancer

\section{Introduction:}

Cancer is an important public health problem, not only worldwide but also in the country, where its incidence has been seen, with a growing trend in recent years; it is a disease with high morbidity and mortality; It is one of the most complicated processes that medicine faces, due to its complex, diverse and multi-causal nature. Cancer becomes a dreaded word for those who do not have it and unpronounceable for those who suffer from it. It is irreversible and progressive in nature, it can be due to multiple causes capable of producing mutations and important genetic changes in the cell structure. Despite studying the effect of some genes on the cell cycle, there is no clear evidence of their role in tumor cell metabolism. The prognosis of this disease largely depends on factors related to the host, the location of the tumor, and the time at which the diagnosis is made. The family and the social environment play an important role as well as the possibilities of receiving treatment. At present, cancer represents a great social challenge, since its incidence increases with the economic and industrial development of the countries, as well as with the improvement of health systems. The incidence of cervical cancer varies considerably from one region of the world to another, with differences of up to 20 times between the highest and lowest incidences.

Cervical cancer or cervical cancer begins in the cells that line the cervix, the lower part of the uterus (womb). The cervix connects the body of the uterus to the vagina. It starts when cells start to grow out of control.

There is a specific point called the transformation zone. The exact location of the transformation zone changes as you age and if you give birth. It is characterized by the fact that most cervical (cervical) cancers originate in cells in this area.

These cells do not suddenly become cancerous, but first the normal cells of the cervix gradually develop abnormal changes that are called 
precancerous changes. Cervical (cervical) cancers start from cells with precancerous changes (pre-cancers), only some of the women with these precancerous changes will develop cervical cancer.

\section{Materials and Methods:}

A detailed bibliographic search of information published since 2015 is carried out, in the databases pubmed, Elsevier, scielo, Update, medline, national and international libraries. We use the following descriptors: Lymphadenectomy, laparoscopic-vaginal, cervical cancer. The data obtained oscillate between 5 and 15 records after the use of the different keywords. The search for articles was carried out in Spanish and English, it was limited by year of publication and studies published since 2015 were used.

\section{Results:}

Laparoscopy is the best minimally invasive technique to select these patients, since peritoneal cytology can be performed and lumboaortic lymph node involvement can be evaluated. Pelvic lymph node status does not affect pelvic radiation. Another benefit of pre-therapeutic laparoscopy is the possibility of performing ovarian transposition in premenopausal women [1].

Hysterectomy is one of the very common surgical procedures in the gynecology specialty, approximately $90 \%$ of these are performed for benign causes. The vaginal and laparoscopic routes are less invasive and are associated with a shorter recovery time, fewer complications, lower financial costs and better cosmetic results, which is why the American Association of Laparoscopic Gynecologists, in agreement with the American College of Obstetricians and Gynecologists recommend it for benign conditions $[2,3]$.

Reich introduced laparoscopic hysterectomy and since then this novel method has been improved but its acceptance in surgical practice is slow due in part to the little interest of surgeons in this technique, to economic factors and to the non-inclusion of this procedure in surgical procedures. Residency programs [4].

Three types of hysterectomies are currently used: vaginal hysterectomy, abdominal hysterectomy, and minimally invasive hysterectomy. The technique to use depends on many factors, including the presence of adnexal disease, size of the uterus, parity. Abdominal hysterectomy is used for the treatment of both benign and malignant diseases of the uterus, allows adnexal surgery and is very useful in case of associated pelvic diseases such as endometriosis or adhesions. However, it is an invasive, bleeding operation, very painful postoperatively and with a long recovery period, which limits the patient from returning to her usual tasks and work [5].

Llanes. [6], concluded that laparoscopic hysterectomy is more effective than abdominal hysterectomy $(\mathrm{p}=0.80)$. Laparoscopic hysterectomy offers a reduction in the amount of bleeding, less postoperative pain, shorter hospitalization time, among others, coinciding with Díaz L, [7], who concludes that laparoscopic hysterectomy is more effective than abdominal hysterectomy, since bleeding mean was $98.3 \mathrm{ml} \pm 42.3$, there were no intraoperative complications; agrees with Darin C, [8], who concludes that laparoscopic hysterectomy is more effective than abdominal hysterectomy, presenting advantages such as recovery of intestinal mobility at 48 hours. Regarding the days of hospital stay, laparoscopic surgery averaged 2.5 days, while in open surgery it was 5.1 days, $(\mathrm{P}<0.0003)$.

Barreras, [9] concluded that laparoscopic hysterectomy is more effective and safer; the surgical time and blood loss averages were one hour 40 minutes and $114 \mathrm{~mL}$, the use of the laparoscopic route allows an early postoperative recovery with rapid reincorporation to the work and social life of the patients, which also coincides with Ferrer H. [10] who concluded that laparoscopic hysterectomy is more effective because it has greater biological, social and economic advantages than conventional hysterectomy. Navarro. [11] Concluded that laparoscopic hysterectomy was more effective, with greater advantages, such as shorter hospitalization time; early return to work, social and family life. Similarly, Marquéz J, [12], concludes that laparoscopic hysterectomy is more effective because it does not present perioperative complications, re-interventions, or mortality and a short postoperative stay.

Vesperinas, [13], concluded that both techniques are effective, taking into account their advantages and disadvantages. Abdominal hysterectomy should be considered in patients in whom the laparoscopic approach is not indicated. The operative time was significantly longer in the HVLP group compared to the HAT group (95.5 v / s 74.0 minutes, $\mathrm{p}<0.001)$ and the latter, in turn, longer than that of the HV group $(74,0 \mathrm{v} / \mathrm{s} 52.9$ minutes, $\mathrm{p}<0.001$ ). The patients who underwent abdominal hysterectomy had more postoperative complications. Hospital stay was longer in the HAT group, which is consistent with other studies in this regard. [14]

\section{Discussion:}

Despite early detection methods and strategies to reduce its incidence, cervical cancer continues to be a health problem in the world. Treatment for early stages is surgical choice. With the aim of reducing surgical morbidity, without compromising the oncological result, minimally invasive techniques have emerged that have shown safety in these aspects. Laparoscopic radical hysterectomy in uterine neck cancer was initially described by Canis et al. In 1990. The development of surgical instruments and the chain of vision, as well as the learning and training in laparoscopy of the operating surgical team, allows this highly complex procedure to be performed in our environment. [15-16]

Currently, abdominal hysterectomy is frequently applied worldwide. Its main indication is uterine fibroma, fibroleiomyoma or uterine leiomyoma. In abdominal hysterectomy, patients are exposed to possible perioperative and postoperative complications, which should be taken into account when choosing the operative technique. Likewise, technical principles must be followed that mainly avoid septic complications, since it is a potentially contaminated operation, where the vaginal dome is opened [17].

In minimally invasive hysterectomy (MMI) a part of the procedure is performed laparoscopically. This method requires more surgical experience and training than vaginal or abdominal hysterectomy. The proportion of HMI has been gradually increasing within the surgical community, due to the recognition of advantages such as: little blood loss, possibility of treating an adnexal condition and associated pelvic diseases, minimal invasiveness, little postoperative pain, reduction of hospital stay and rapid return of the patient to her usual activities [18]. The objective of laparoscopic hysterectomy is to convert an abdominal hysterectomy into a vaginal one, selecting each case properly and without forgetting the classic patterns. Some of its benefits are: better approach with smaller incisions, less perioperative blood loss, reduced hospital stay, faster return to daily activities, lower rate of wound or abdominal wall infections, lower incidence of hernias [19].

Likewise, postoperative pain is less, due to less tissue damage and a reduction in the inflammatory response. In this sense, several investigations support the fact that with laparoscopic techniques the hospital stay is reduced and recovery is faster. Similarly, the aesthetic factor should not be forgotten, since micro incisions are made [20]. However, the surgical time is similar and on some occasions it may be longer; Access to this technique is still limited for the majority of the population, mainly due to the need for adequate technical equipment and the small number of professionals trained to perform this procedure [21]. 


\section{Conclusion:}

Currently, and based on technological and scientific evolution in the field of science and medicine, laparoscopic hysterectomy should be considered as the surgical approach of choice, as it is a surgical technique with greater benefits for the patient, it is an effective technique that presents less bleeding, shorter hospitalization time, return to daily activities in less time, less post-operative pain; compared to total abdominal hysterectomy, which presents greater intra- and post-operative complications. Within the care protocols for female patients in initial stages of cervical cancer, this technique should be placed at the top, based on the information and studies collected.

\section{References:}

1. Gonzalo Vesperinas A, Carlos Rondini S, Carlos Troncoso R, Boris Morán V, Marco Levancini A, César Avilés Z, Fernando Troncoso R. Histerectomía Vaginal, Abdominal y Vaginal asistida por Laparoscopia: Un análisis prospectivo y aleatorio. REV CHIL OBSTET GINECOL 2005; 70(2).

2. García E, Romero E. Histerectomía vaginal en úteros no prolapsados: a propósito de 300 casos. ObstetGinecol 2008; abr.; 34(1) 09-29.

3. Meikle S Weston N, Orleans M. Complications and recovery from laparoscopy-assisted vaginal hysterectomy compared with abdominal and vaginal hysterectomy. ObstetGynecol, 2011; jun; 93(3) 09-29.

4. Kadar N. Implementation of laparoscopic hysterectomy in community hospitals. GynecolLaparoscopists 2010; jul;95(3) 10-12.

5. Garry R. Comparison of hysterectomy techniques and costbenefit analysis. ClinObstetGynaecol 2011; abr; 11(3) 10-12.

6. Arturo Llanes Castillo, Armando Treviño Rodríguez, Mary Tere Cruz Almaraz y Miriam Janet Cervantes López. Histerectomía Laparoscópica Total versus Histerectomía Convencional en pacientes trabajadoras de petróleos Mexicanos. Medicina, Salud y Sociedad. Revista Electrónica. ISSN 2007-2007

7. Díaz Ortega I, Martínez Martínez-Pinillo Á, Castillo Y, Barreras González J, Pereira Fraga J, Masa Bravo N. Histerectomía radical video laparoscópica. Scielo.sld.cu. 2018.

8. Cecilia Darin, Julián Di Guilmi, Romina Verdura, Juan Sardi, Gustavo A. Maya. Histerectomía radical laparoscópica: ¿un nuevo estándar en el tratamiento del cáncer de cuello uterino? Fronteras en Medicina 2016;11(1):13-16

9. Barreras González J, Díaz Ortega I, López Milhet A, Pereira Fraga J, Castillo Sánchez Y, Sánchez Hernández E. Histerectomía laparoscópica en 1599 pacientes. Scielo.sld.cu. 2018

10. Ferrer Robaina H, Clavijo Torres R, Zayas Díaz L, Rodríguez Cruz Y, Mesa Izquierdo O, Blanco Amaro E. Histerectomía laparoscópica. Scielo.sld.cu. 2018].

11. Hernando Navarro-Newball, M.D. Histerectomía laparoscópica: Sistematizacion del procedimiento y propuesta para programas de capacitación. Colomb Med 2005; 36: 115119.

12. García Rodríguez M, Romero Sánchez R. Histerectomía: Evaluación de dos técnicas quirúrgicas. Scielo.sld.cu. 2018.

13. Castillo A, Rodríguez A, Almaraz M, López M. Histerectomía Laparoscópica total versus Histerectomía convencional en pacientes trabajadoras de petróleos Mexicanos. Revistas.uv.mx. 2018.

14. MsC. Joaquín Márquez Hernández, Dr. Alejandro Barrabí Díaz, Dr. Bárbaro Agustín Armas Pérez y Dr. Jorge Rubinos de la Rosa. Histerectomía abdominal en un servicio de cirugía general. Medisan 2014;18(2):169

15. Canis M, Mage G, Wattiez A, Pouly JL, Manhes H,Bruhat MA. Does endoscopic surgery have a role in radical surgery of cancer of the cervix uteri? J Gynecol Obstet Biol Reprod (Paris) 1990; 19(7):921.

16. Nezhat CR, Burrell MO, Nezhat FR, Benigno BB, Welander CE. Laparoscopic radical hysterectomy with paraaortic and pelvic node dissection. Am J Obstet Gynecol 1992;166(3):865.

17. Garry R. Comparison of hysterectomy techniques and costbenefit analysis. ClinObstetGynaecol 2011; abr [citado el 5 de mayo de 2018]; 11(3) 10-12.

18. Nieboer T, Johnson N, Lethaby A, Surgical approach to hysterectomy for benign gynaecological 2009; abr [citado el 8 de mayo de 2018]; 9 (3) 52-54.

19. Sardiñas R. Histerectomía laparoscópica: experiencia en el Hospital Clínico Quirúrgico Hermanos Ameijeiras. [Tesis]. La Habana: Universidad de Ciencias Médicas de La Habana; 2013.

20. Dominguez Novo A. Histerectomía total versus subtotal. Tokio Ginecología práctica. 2002; 61: 221-231.

21. Rodriguez Hidalgo N. Cirugía Ginecológica y Obstétrica. La Habana: Editorial Pueblo y Educación; 1993.

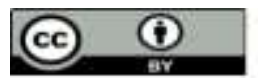

This work is licensed under Creative Commons Attribution 4.0 License

To Submit Your Article Click Here: Submit Manuscript

DOI: $10.31579 / 2642-9756 / 084$
Ready to submit your research? Choose Auctores and benefit from:

$>$ fast, convenient online submission

$>$ rigorous peer review by experienced research in your field

$>$ rapid publication on acceptance

$>$ authors retain copyrights

$>$ unique DOI for all articles

$>$ immediate, unrestricted online access

At Auctores, research is always in progress.

Learn more auctoresonline.org/journals/women-health-care-and-issues 